\title{
Microbial Etiology of Duck Mortality in Odisha, India
}

\author{
Udit Narayan Bariha $^{1 *}$, Rajashree Mishra', AK Kundu ${ }^{2}$, P.K.Rath ${ }^{3}$, \\ Chinmoy Mishra ${ }^{4}$, Sisir Das ${ }^{5}$ and N. Soren \\ ${ }^{1}$ Department of Veterinary Microbiology, ${ }^{2}$ Department of Veterinary Physiology, ${ }^{3}$ Department \\ of Animal Breeding and Genetics, ${ }^{4}$ Department of Veterinary Physiology, College of \\ Veterinary Science and Animal Husbandry, OUAT, Bhubaneswar, India \\ *Corresponding author
}

\section{Keywords}

Duckmortality, Microbial etiology, Breeds of duck

Article Info

Accepted: 12 July 2019 Available Online: 10 August 2019

\section{A B S T R A C T}

In the present study 128 samples collected from 66 ducks of various breeds like Batak(28), Moti(34) and Khaki Campbell (6) out of which 112 number of samples from 52 dead birds and 16 number of samples from live birds. blood, liver, swabs from femur bone marrow and also swabs from foot lesions were collected consists of 128 samples in which blood sample (12), swabs from foot lesions(26) of live birds and liver(22), lungs(30) and swab from bone marrow (38) of dead birds. All the samples were processed for routine microbial isolation and identification. Pasteurella species was found to be the most predominant isolate (16\%) followed by Pseudomonas species was found to be $(11.2 \%)$ and E.coli (55\%) where as fungal isolates like Aspergillus species was found to be (18\%). Pasteurella species were cultivated in 5\% sheep blood agar and McConkey's agar whereas Aspergillus species in SDA by routine inoculation procedure. The ducks were ranging from 2 to 16 weeks of age mostly from unorganised sectors of Odisha. Ducklings were found to be more prone to Pseudomonas and Aspergillus species in comparison to adult ones on antibiotic sensitivity test.it was revealed that tetracycline, doxycycline, oxytetracycline, found to be least sensitive in disk diffusion method. Whereas gentamicin, and ciprofloxacin were found to be highly sensitive against E.coli and gentamicin, amikacin, tobramycin were found to be highly sensitive against Pseudomonas species. Most of the gram negative bacteria isolated in the present study like Pasteurella species, Pseudomonas species and E. coli species were found to be resistant to tetracycline, amphotericin-B. griseofulvin were found to be highly sensitive for Aspergillus species isolated in the present study.

\section{Introduction}

Mostly ducks are reared in coastal districts of odisha like kendrapada, cuttack, puri and paradeep and rural parts of Odisha. Mainly indigenous ducks are reared for where there is source of water in the form of ponds. These indigenous water fowls are of two types one in Batak and other in Moti (Muscovy). According to 2003 data the total numbers of 
ducks present in Odisha was 6,10,000. Commercial rearing of khaki Campbell ducks are practised in coastal areas of Odisha. So in order to treat the water fowls expediently a vivid knowledge regarding the common causative agents of the infectious diseases and its antibiotic sensitivity profile is of paramount importance.

\section{Materials and Methods}

\section{Sample collection}

In the present study a total number of 128 dead and live duck samples were collected from kendrapada, Puri, Paradeep and ADRI (Animal Disease Research Institute) Cuttack during the period of December, 2018 to May, 2019. Different organs like liver, lungs, swab sample from bone marrow of dead birds and blood sample, swabs from foot lesions were collected from live birds and processed for routine microbial isolation (Fig. 1).

\section{Microbial analysis}

The samples were inoculated in standard broth like Brain heart infusion broth (BHI) and incubated at $37^{\circ} \mathrm{c}$ for $24 \mathrm{hrs}$. Various selective media like Pseudomonas isolation agar, McConkey lactose agar and blood agar were used for isolation of different bacteria. Identification of the organism was done with reference to colony morphology (size, colour and nature), pigment production along with various biochemical test.

\section{Mycological analysis}

For fungal isolation samples were inoculated into Sabouraud dextrose agar (SDA) and Potato dextrose agar(PDA) and incubated at $37^{\circ} \mathrm{c}$ ngfor 3-4 days. Identification of the fungus has carried out by lactophenol cotton blue staining along with observing colour, hyphae and nature of colony.

\section{Antibiogram study}

In-vitro antimicrobial study was carried out by using Muller Hinton agar M/S Hi-Media Laboratories Ltd. Mumbai for bacterial isolates and Muller Hinton agar with 2\% glucose and $0.5 \% \mathrm{mcg} / \mathrm{ml}$ methylene blue was used for fungal isolates (Bauer et al., 1966). The antibiotic discs like ciprofloxacin (CIP30mcg), ampicillin (AMP-10mcg), tetracycline (TE-1mcg), doxycycline (DO30mcg), erythromycin (E-10mcg), chloramphenicol (C-20mcg), cotrimoxazole (COT-25mcg), amoxyclav (AMC-30mcg), gentamicin (GEN-10mcg), and Amikacin (AK-30mcg) were used for bacterial isolates. Griseofulvin (GS-), Amphotericin-B(AP20mcg), Tobrmycin (TOB-30mcg) ketoconazole (KT-50mcg) and fluconazole (FLC-10 mcg) were used for fungal isolates. All the disc were obtained from Hi-Media, Mumbai, India. The results were recorded according to criteria set by clinical and laboratory standards institute (CLSI) (Wayne, 2009).

\section{Results and Discussion}

In the present study, 90 bacterial isolates and 37 number of fungal isolates were obtained by routine microbial isolation. E.coli (70/127) was found as the most predominant bacterial isolates (Adziety et al., 2011) followed by Pasteurella species (20/127). Similarly Aspergillus species (23/127) was the predominant fungal isolates followed by Pseudomonas species (14/127) which shows $18 \%$ of the fungal infection out of total sample collected. This result is similar to that of study of (Samuelson et al., 1984) Pink colour colony was produced by E.coli $(\mathrm{n}=70)$ on McConkey lactose agar whereas Pasteurella species $(\mathrm{n}=20)$ produces small, glistening and dew drop like colony on blood agar plate this result is in agreement with the findings of (Bhattacharya, 2005). Aspergillus 
species produces characteristic wooly and green colonies where as Pseudomonas species flurescin pigment (greenish colour) on MHA plates. Club shaped vesicle with unseriate conidia was identified on lactophenol cotton blue staining of Aspergillus species. on analysis of antibiogram susceptibility pattern produced by various antibiotics and antifungals, it was found that E.coli was highly sensitive to and gentamicin and cipro loxacin. Pasteurella species isolates were sensitive to amoxyclav, chloramphenicol, gentamicin and co-trimoxazole. This study is in agreement with (Bauer et al., 1966) and (Bhattacharya A. 2005). Pseudomonas species isolates were sensitive to gentamicin, amikacin and tobramicin and Aspergillus species isolates were highly sensitive to griseofulvin (Fig. 2-5).

Table.1 The distribution of samples collected from various breeds of Ducks $(n=66)$

\begin{tabular}{|c|c|c|c|c|c|c|c|}
\hline \multirow[b]{2}{*}{ Si no. } & \multirow[b]{2}{*}{ Breed } & \multirow[b]{2}{*}{ age } & \multicolumn{3}{|c|}{ Dead birds } & \multicolumn{2}{|c|}{ Live birds } \\
\hline & & & Liver & Lungs & $\begin{array}{l}\text { Swabs of } \\
\text { femur } \\
\text { bone }\end{array}$ & $\begin{array}{l}\text { Swabs of } \\
\text { foot } \\
\text { lesions }\end{array}$ & Blood \\
\hline \multirow[t]{2}{*}{1.} & \multirow{2}{*}{$\begin{array}{l}\text { Indigenous } \\
\text { Batak } \\
\qquad(\mathrm{n}=30)\end{array}$} & $\begin{array}{c}0-4 \text { week } \\
(n=20)\end{array}$ & 5 & 10 & 9 & - & - \\
\hline & & $\begin{array}{l}\text { 4-16 week } \\
\quad(n=10)\end{array}$ & 3 & 4 & 7 & 8 & 5 \\
\hline \multirow[t]{2}{*}{2.} & \multirow{2}{*}{$\begin{array}{l}\text { Indigenous } \\
\text { Moti(Muscovy) } \\
\quad(n=25)\end{array}$} & $\begin{array}{l}0-4 \text { week } \\
\quad(n=15)\end{array}$ & 4 & 5 & 7 & - & - \\
\hline & & $\begin{array}{l}\text { 4-16 week } \\
\quad(n=10)\end{array}$ & 3 & 4 & 6 & 11 & 3 \\
\hline \multirow[t]{2}{*}{3.} & \multirow[t]{2}{*}{$\begin{array}{l}\text { Khaki } \\
\text { Campbell } \\
\qquad(\mathrm{n}=11)\end{array}$} & $\begin{array}{l}0-4 \text { week } \\
\quad(n=7)\end{array}$ & 4 & 4 & 5 & - & - \\
\hline & & $\begin{array}{l}\text { 4-16 week } \\
\qquad(n=4)\end{array}$ & 3 & 3 & 4 & 7 & 4 \\
\hline
\end{tabular}

Table.2 Prevalence and isolation of different microbial isolates from duck samples

\begin{tabular}{|l|c|c|}
\hline \multicolumn{1}{|c|}{$\begin{array}{c}\text { Name of the Bacterial } \\
\text { isolates }\end{array}$} & No. of isolation & Isolation (\%) \\
\hline E.coli & 70 & 55 \\
\hline P.multocida & 20 & 16 \\
\hline Aspergillus species & 23 & 18 \\
\hline Pseudomonas species & 14 & 11.2 \\
\hline
\end{tabular}


Table.3 Comparative study of antimicrobial sensitivity test for bacterial isolates

\begin{tabular}{|c|c|c|c|c|c|c|c|c|c|c|c|c|c|c|c|c|}
\hline $\begin{array}{l}\text { Si } \\
\text { no. }\end{array}$ & $\begin{array}{l}\text { Bacterial } \\
\text { isolates }\end{array}$ & CIP & AMP & TE & DO & $\mathbf{E}$ & $\mathbf{C}$ & COT & AMC & GEN & TOB & AK & GS & $\mathbf{A P}$ & KT & FLC \\
\hline 1. & E.coli & 21 & 13 & 11 & 12 & 14 & 13 & - & - & 15 & - & - & - & - & - & - \\
\hline 2. & P.multocida & 21 & - & - & - & - & 18 & 16 & 18 & 15 & - & 15 & - & - & - & - \\
\hline 3. & $\begin{array}{l}\text { Pseudomonas } \\
\text { species }\end{array}$ & 16 & - & - & - & - & 12 & - & - & 15 & 15 & 17 & - & - & - & - \\
\hline 4. & $\begin{array}{l}\text { Aspergillus } \\
\text { species }\end{array}$ & - & - & - & - & - & - & - & - & - & - & - & 21 & 17 & 20 & 20 \\
\hline
\end{tabular}

CIP-Ciprofloxacin, AMP-Ampicillin, TE-Tetracycline, DO-Doxycycline, E-Erythromycin, C-Chloramphenicol, COT-Co-trimoxazole, O-Oxytetracycline, AMC-Amoxyclav, GEN-Gentamicin, AK-Amikacin, GS-Griseofulvin, AP-Amphotericin-B, KT-Ketoconazole, FLC-Fluconazole

*Not all microbials are tested against all microbial isolates 


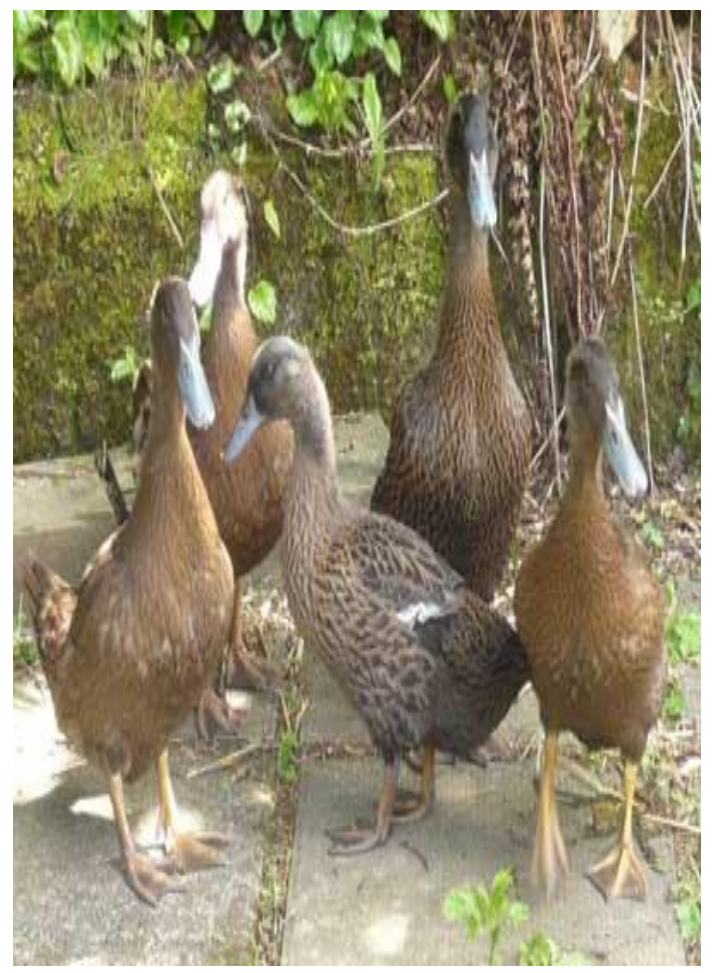

Figure.1 Khaki Campbell duck

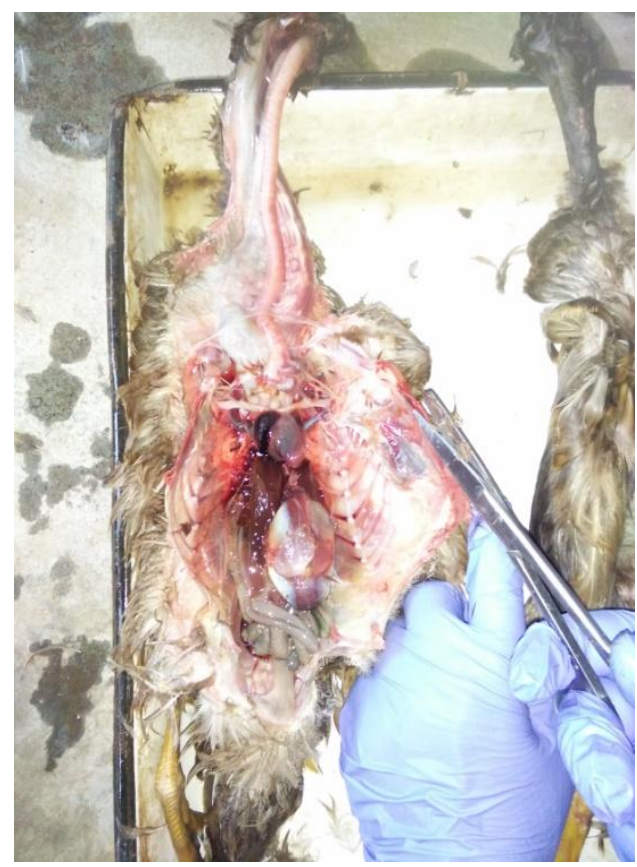

Figure.1(c) PM of dead duckling

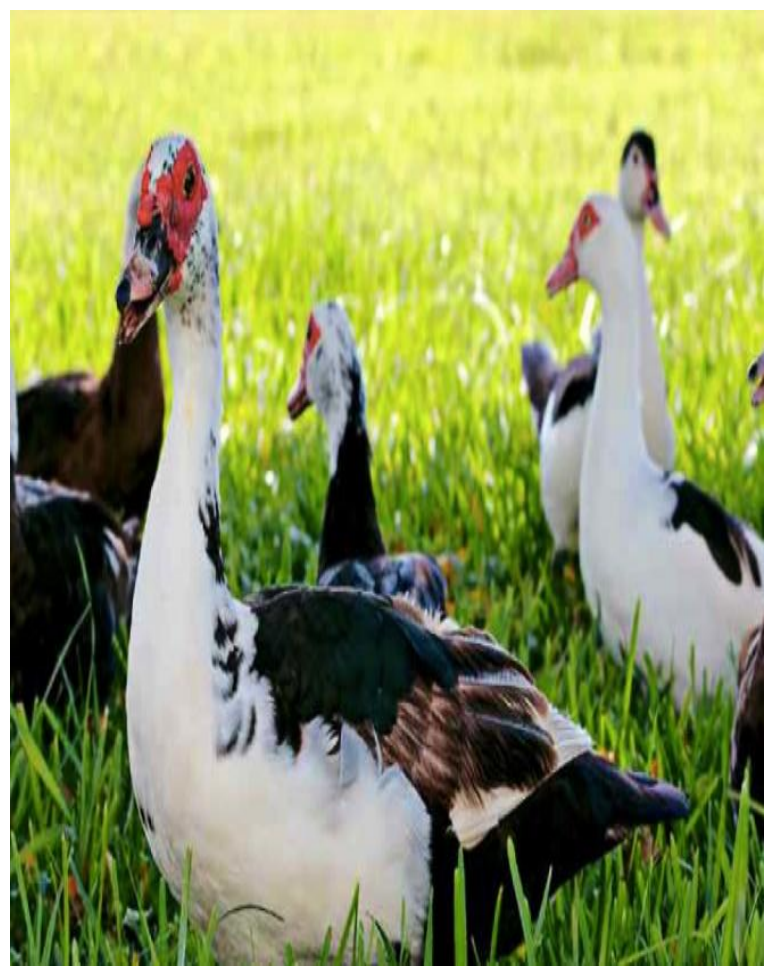

Figure.1(b) Muscovy(Moti) duck

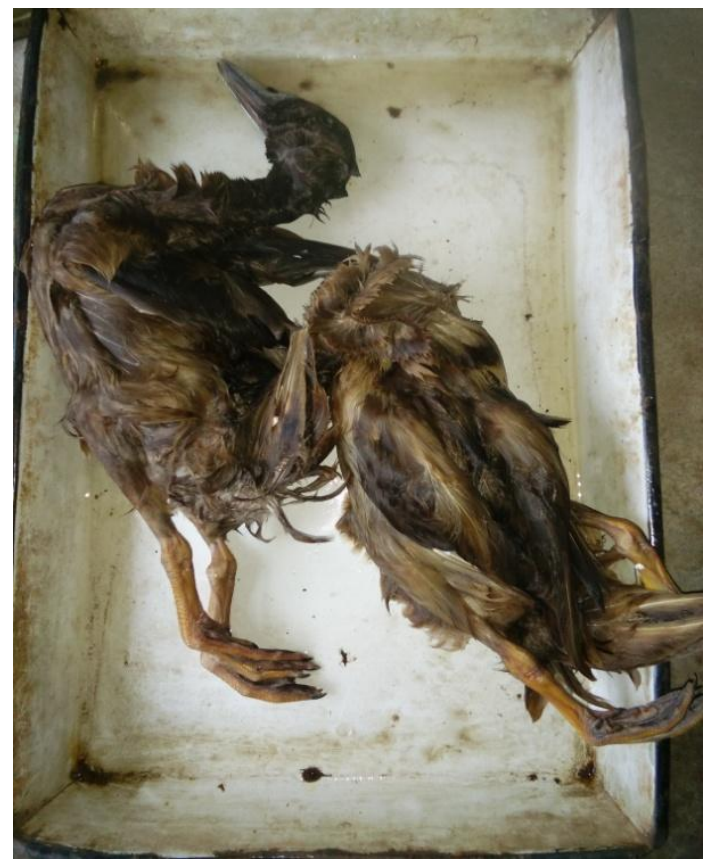

Figure.1(d) dead khaki Campbell duckling 
Int.J.Curr.Microbiol.App.Sci (2019) 8(8): 1577-1585
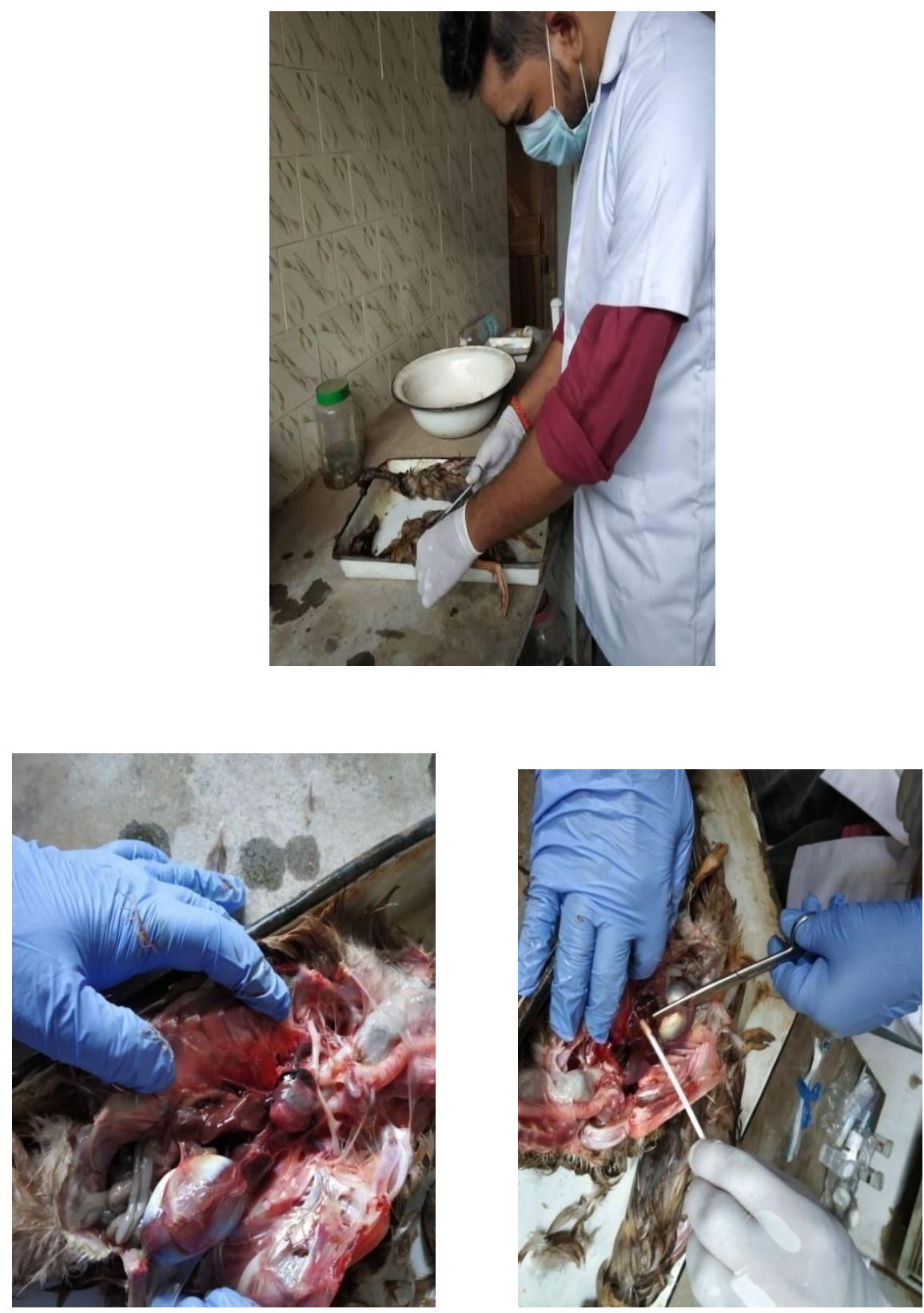

Fig.2 Collection of sample for khaki Campbell and white pekin breed. 


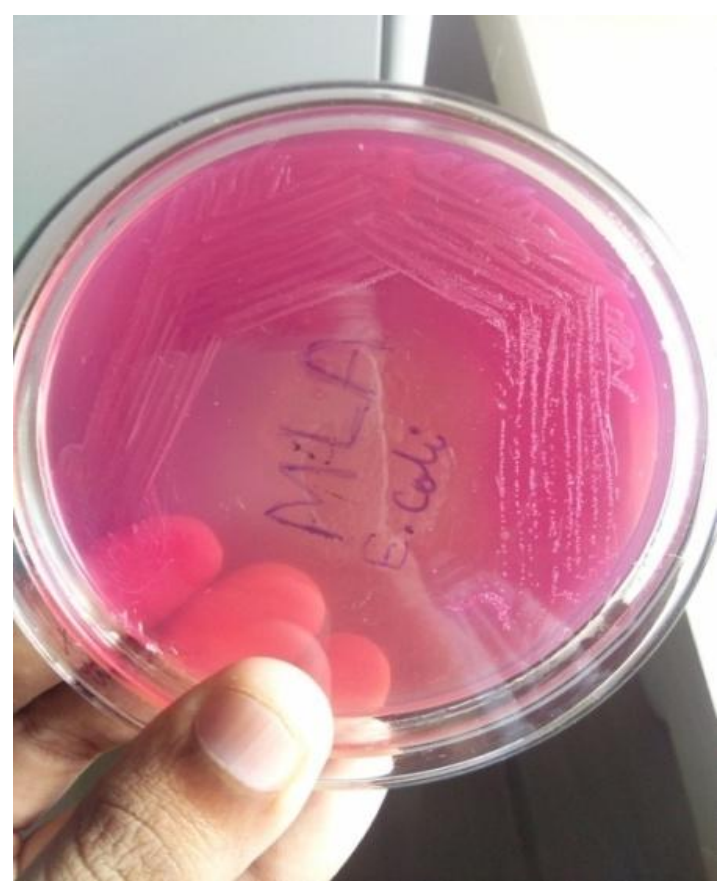

Fig.3 E. coli culture on MLA plate

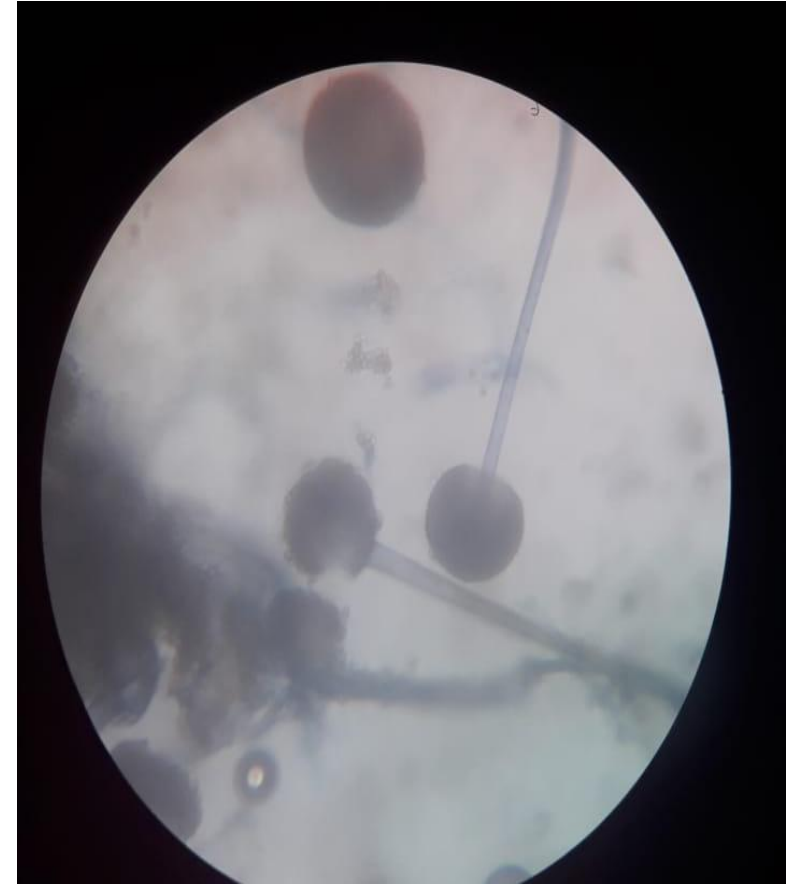

Fig.4 Lactophenol cotton blue staining of Aspergillus species

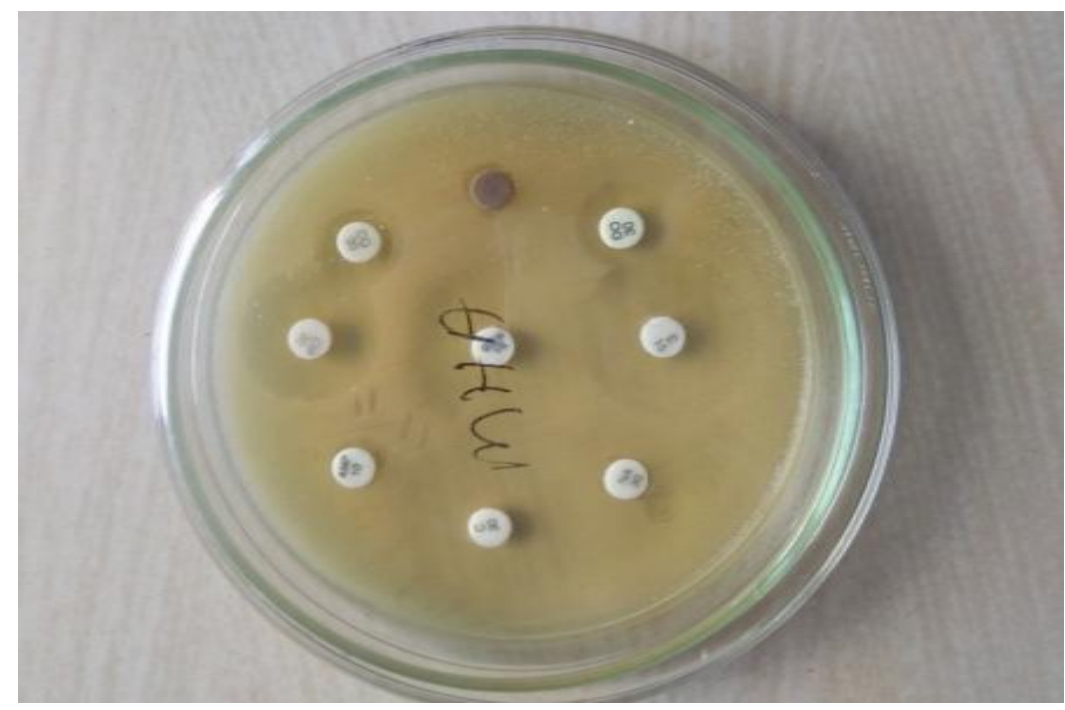

Fig.5 Antibiotic sensitivity plate for E. coli 
In case of E.coli antibiotics like ciprofloxacin, ampicillin, tetracycline, doxycycline, erythromycin, chloramphenicol and gentamicin showed inhibitory zone of 21,13 , $11,12,14,13$, and $15 \mathrm{~mm}$ respectively. In case of Pasteurella species ciprofloxacin, chloramphenicol, cotrimoxazole, amoxyclav, gentamicin and amikacin showed inhibitory zone of $21,18,16,18,15$ and $15 \mathrm{~mm}$ respectively. In case of Pseudomonas species gentamicin, tobramicin, amikacin, ciprofloxacin, and chloramphenicol showed inhibitory zone of $15,15,17,16$, and $12 \mathrm{~mm}$ respectively. Similarly, in case of Aspergillus species griseofulvin, amphotericin- $\mathrm{B}$, fluconazole and ketoconazole showed inhibitory zone of $21,17,20$ and $20 \mathrm{~mm}$, respectively. Inhibitory zone of different microbial can be found in table no.3.

Therefore it is concluded, on the basis of present observation the most prevalent micro organism in indigenous ducks of Odisha was Pseudomonas species followed by Pasteurella species, E.coli whereas fungal agent like Aspergillosis was more common in ducklings ( 0 to 4 weeks of age). Further study in more detail in qualitative microbial load is required to combat the disease prevalence in densely populated indrustrialized duck production.

\section{References}

Adziety, F and J. Corry, 2011. A comparison between hippurate hydrolysis and multiplex PCR for differentiating $C$. coli and C. jejuni Trop. Life Sci. Res.,22:91-98.

Ang, C.W., De Klerk, M.A., Endtz, H.P., Jacobs, B.C., Laman, J.D., Van der Meche, F.G., Van Doorn, P.A., 2001. Guillain-Barre syndrome and Miller Fisher syndrome-associated Campylobacter jejuni lipopolysaccharides induce anti-GM1 and anti-GQ1b antibodies in rabbits. Infection and Immunity 69, 24622469.

Bauer AW, Kirby WMN, Sherris JC and Turck M (1966), Antibiotic susceptibility testing by a standardized single disk method. American Journal of Clinical Pathology 45: 493

Fallacara DM, Monahan CM, Morishita TY, Wack RF: Fecal shedding and antimicrobial susceptibility of selected bacterial pathogens and a survey of intestinal parasites in free-living waterfowl. Avian Dis 45: 128135,2001

Feng,P and S.D. Weagant 2009. Bacteriological analytical manual. $8^{\text {th }}$ edition chapter 4,http://www.fda.gov/food/sciencerese arch/LaboratoryMethods/Bacteriologi calAnalytical ManualBAM/UCM064948.

Klatte, J.M., Clarridge III, J.E., Bratcher, D., Selvarangan, R., 2012. A longitudinal case series description of meningitis due to Streptococcus gallolyticus subsp. pasteurianus in infants. J. Clin. Microbiol. 50 (1),57-60.

Koo, H. J. and Woo, G. J. (2011) Distribution and transferability of tetracycline resistance gene determinants in E.coli isolated from meat and meat products. Int $j$ food microbial 145, 407-413.

Kumar AA, Harbola PC, Rimler RB and Kumar PN.(1996). Studies on Pasteurella multocida isolate of animal and avian origin from India. Indian J. Comp. Micro. Immunol. Infec. Dis. 17: 120-124.

Maity, D.K., Chatterjee, A., Guha, C. And Biswas U. (2012). Isolation, characterization and antibiotic sensitivity of Pasteurella multocida from incidence of duck cholera in Khaki Campbell and Vigova Super-M duck in Tripura. Indian Vet. J. 82: 
203-205

Padhi, M.K. and SAHOO, S.K. (2011) Evaluation of Native and Khaki Cambell ducks and their crosses. Indian Veterinary Journal 88:54-56.

Samuelson DA, Andresen TL and Gwin RM(1984) Conjuctival fungal flora in horse cattle, dogs and cats. L Am Vet Med Assoc 184:1240-1242

Sarba, E.J., Borena B.M. and Teshale, A. (2019). Cloacael carriage and multidrug resistance Escherichia coli O157:H7 from poultry farms, eastern Ethiopia. JVet Med
Sharma, M., Hoover, D.G. and Markland S.M. (2017). Comparative virulotyping of extended spectrum cephalosporin resistant $E$. coli isolated from broilers, humans on broiler farms and in the general population and UTI patients, Vet. Microbiol 194 55-61.

Wang, Y., Tang, C., Yu, X., Xia, M., Yue, H., 2010. Distribution of serotypes and virulence associated genes in pathogenic Escherichia coli isolated from ducks. Avian Pathol.39, 297-302

\section{How to cite this article:}

Udit Narayan Bariha, Rajashree Mishra, AK Kundu, P.K. Rath, Chinmoy Mishra, Sisir Das and Soren, N. 2019. Microbial Etiology of Duck Mortality in Odisha, India. Int.J.Curr.Microbiol.App.Sci. 8(08): 1577-1585. doi: https://doi.org/10.20546/ijcmas.2019.808.186 